\title{
The Attitudes of Turkish Teachers to New Applications
}

\author{
Sedat Maden \\ Department of Turkish Language Education, Faculty of Education, Giresun University, Turkey
}

Copyright $(2016$ by authors, all rights reserved. Authors agree that this article remains permanently open access under the terms of the Creative Commons Attribution License 4.0 International License

\begin{abstract}
With developments in technology and changes in living conditions, significant improvements have occurred in education field. In this study, it has been aimed to determine the attitudes of Turkish teachers to new applications with respect to some variables like gender, seniority, education level and duty place. The sample of the study consists of 125 Turkish teachers working in Erzurum, Trabzon, Ordu, and Sivas cities. The data of the research study was gathered through Survey for the Attitudes of Turkish Teachers on New Applications (SATTNA), prepared by the researcher, and analyzed by using techniques of percentage, frequency and Anova in SPSS. Based on the present study, it has been concluded that Turkish teachers delivered their attitudes on new approaches/applications with the average level $(\bar{x}=3.15)$. In addition, it has been found that female Turkish teachers who had 1-5 years' work experience and have worked in city centers held more positive attitudes to new applications compared to the others.
\end{abstract}

Keywords Turkish Teachers, New Applications, Innovations in Education, Attitude

\section{Introduction}

The developments in science and technology have provided changes in our understanding of education and education applications as well as providing changes in our lives in many ways. As a result of these changes, a new education model was needed to nurture people who met the requirements of today's world. In this new education model, every individual who lives in this information society should acquire the ability to reach information, use it and contribute to it for new circumstances [1]. According to Sonmez [2] the changing aims of education are to nurture people who can think critically, produce multiple solutions to problems, take responsibility, improve themselves with the knowledge of where and how to get information, are tolerant and can view the incidents from many different perspectives $[3,4]$.

The social aim of education is to nurture individuals who are open to changes, creative, productive and who use information efficiently. The most effective way of accomplishing this goal is to train qualified teachers. A qualified teacher has the ability to renew her/himself continuously in direct proportion to developments in science and technology [5, p.156]. A teacher in an education system performs her/his teaching duty with a constant dynamism and change. Therefore, a teacher should improve her/himself continuously by using different resources [6, p.35]. There are many studies in related literature which focused on the subjects on indicators of qualified/unqualified teachers such as improving her/himself as a teacher, adapting to her/himself or show resistance as a teacher to innovations and changes $[7,8,9,10,11]$. The findings of these research studies showed that teachers need to improve themselves by having the knowledge and the abilities which the modern world needed because they are supposed to be role models for and to guide new generations. Because, societies' expectations from students rise, expectations from teachers increase naturally [12].

With the effect of rapidly developing technology and changing living conditions, significant changes in education, particularly since 2005, have occurred in Turkey from primary education to higher education. Most changes were put into curriculum so it caused changes in educational equipments/materials and teaching methods and techniques. One of the areas which essential changes occurred is the area of teaching and learning Turkish language.

A new approach which is based on student centered learning and teaching model and individual differences has been adopted with the changes which have been applied to Turkish curriculum since 2004 in primary education, since 2005 in upper-primary education; with the changes which have been applied to Turkish Language Teacher Education Undergraduate Program since $2006[1,13,14]$. After the newly-adopted approach, new educational equipments/materials and teaching methods and techniques have begun to be used in Turkish lessons in primary and upper-primary schools and in Turkish Language Teacher Education.

Teachers have the biggest responsibility for education of individuals who modern societies need. This fact increased the importance of teacher factor which is one of the main factors in education. Well-designed school buildings, well-planned educational practices/applications and curriculums, various educational equipments/materials, 
students and quality learning environment are important for quality education. However, teaching skills and pedagogical content knowledge of teachers who are users of above components of an educational system are more important. In other words, the qualities of teachers as implementers of education programs have a big impact on the qualities of above components of an educational system [15]. In addition to this, it can be said that teachers have a significant role on either instructing Turkish classes in primary and upper-primary levels or educating Turkish teacher candidates. It can also be stated that teachers are the stakeholders in education who experience the effects of changes in the process of teaching and the most capable ones who determine the negative sides of these changes. Achieving the aims of all changes for success and quality in teaching Turkish is directly proportionate to teachers' adaptation to and understanding of these changes and their effectiveness. Therefore, teachers should be open to the educational changes and prepared for new applications in education and they should be aware of their needs of pedagogical content knowledge and pedagogical skills.

The Ministry of National Education in Turkey (2008) determined and published the abilities which Turkish language teachers should gain in their pre-service education. The booklet of special domain competencies gives, under the "Ensuring career development in Turkish" domain competency, 3 competencies and 23 performance indicators about teachers renewing themselves and adapting themselves to changes. For example, the competency of "ensuring personal and career development in teaching Turkish" expects a Turkish teacher to have the competencies such as following the various publications on applications of language, literature and teaching process, following art activities related to their profession and attending conferences, panels, scientific meetings and seminars related to Turkish language teaching"'[16, p.57].

Teaching is a profession which requires continuing professional development. Many great and radical changes occur in the world. Therefore, teachers do not only need to adapt themselves to changes but they also need to educate students who are open to changes $[17,18]$. The teachers, who have a significant role in education process, have to use sciences and technological resources efficiently and teach these knowledge and skills. Because of all these reasons, the approaches and motivations of teachers to innovations in education are so important to achieve the goals of an education system and ensure social development. However, it can be said that teachers as the most important stakeholders of an education system do not have always positive approaches to educational developments and changes. Some teachers in Turkey even show resistance to these changes hence the positive effects of these changes in our education system have delayed. Helvac1 [19, p. 2045] developed a scale to investigate the reasons of teachers' resistance to educational changes. He found that teachers showed resistance to educational changes because of their lack of knowledge about change process, their reluctance to take on new duties, new roles and new responsibilities, their inability to manage changes, their belief about ineffectiveness of educational changes, and lack of school facilities. It is likely that Turkish teachers show resistance to educational changes, new programs, approaches and materials related to teaching Turkish, because of above reasons. Therefore, their adaptation to changes takes too much time. It prevents obtaining positive results of new applications to improve success in teaching Turkish on expected time and conditions. Training should be provided in undergraduate and in-service education to overcome teachers' resistance, non-adaptations and negative approaches to changes. In related literature, it can be seen that the researchers investigated teachers' opinions about and approaches to new program, approach and educational technology applications [20,21,22,23,24,25]. However, it has not been determined the approaches of teachers to innovations in general. In this respect, teachers' attitudes to new educational innovations and developments, their resistance and adaptation to these innovations and developments should be investigated for successful teaching.

\section{The Aim of the Study}

This study aims to investigate the attitudes of Turkish teachers to new educational developments/applications based on gender, seniority, duty place and education level variables. In order to do that, the questions below will be answered:

What is the level of attitudes of Turkish teachers to the new educational developments/applications?

What is the effect of gender variable on attitudes of Turkish teachers to the new educational developments/applications?

What is the effect of level of seniority variable on attitudes of Turkish teachers to the new educational developments/applications?

What is the effect of duty place variable on attitudes of Turkish teachers to the new educational developments / applications?

What is the effect of education level variable on attitudes of Turkish teachers to the new educational developments / applications?

\section{Materials and Methods}

\section{Research Methods}

This research study was carried out by using survey method which is one of the descriptive research methods. Single screening model was applied. Single screening model is applied in order to determine how variables are formed one by one, according to their types and quantity [26, p.76].

\section{Sample of the Study}


The sample of the study consists of 125 Turkish teachers who worked in cities of Erzurum (55), Trabzon (25), Ordu (26) ve Sivas (19) in 2014-2015 school year. Of the whole teachers, 56 were males and 69 were females (see Table 1).

Table 1. The number of teachers based on gender, level of seniority and duty place

\begin{tabular}{|c|c|c|c|}
\hline \multirow{2}{*}{ Gender } & Female & Male & \\
\cline { 2 - 4 } Seniority & 69 & 56 & \\
\cline { 2 - 4 } & $\mathbf{1 - 5}$ years & $\mathbf{6 - 1 0}$ years & $\mathbf{1 0 - 1 5}$ years \\
\hline \multirow{2}{*}{$\begin{array}{c}\text { Duty } \\
\text { place }\end{array}$} & City center & District center & Village \\
\cline { 2 - 4 } & 38 & 44 & 43 \\
\hline \multirow{2}{*}{$\begin{array}{c}\text { Education } \\
\text { level }\end{array}$} & Bachelor Degree & $\begin{array}{c}\text { Master's } \\
\text { Degree }\end{array}$ & $\begin{array}{c}\text { Doctorate } \\
\text { Degree }\end{array}$ \\
\cline { 2 - 4 } & $\mathbf{9 7}$ & 22 & 6 \\
\hline
\end{tabular}

\section{Data Collection and Data Analysis}

The information about the Turkish teachers' gender, level of seniority and duty place was gathered through 'Personal Information Form'. A questionnaire named 'Survey for the Attitudes of Turkish Teachers on New Applications (SATTNA) was designed to investigate the attitudes of Turkish teachers to new applications under the light of related literature.

The items on the questionnaire were created by asking the opinions of experts on the field and reviewing the relevant literature. A draft of the questionnaire was examined by 5 academics who were experts on Turkish language education and educational sciences. The number of the items on the questionnaire was 26 in the beginning but, it was decreased to 20 after the experts' recommendations. The reliability level of the questionnaire was determined as (Cronbach Alpha) 0.84 as a result of a pilot study with 60 undergraduates. The questionnaire is a Likert type rating scale comprised of 20 positive and negative statements from 'strongly agree (5)' to 'strongly disagree(1)'. However, two negative statements (first and second one) were reverse-scored (strongly disagree (5)). When the gaps on the scale are assumed to be equal, it was found that score interval coefficient for arithmetic means was 0.80 .

(Score interval $=($ The Highest Score-The Lowest Score $) / 5$ $=4 / 5=0.80$ ). As indicated in Table 2 , this formula was used to determine the evaluation intervals of the data are indicated.

Table 2. Score Interval of Data

\begin{tabular}{|c|c|c|}
\hline $\mathbf{1 . 0 0}-\mathbf{1 . 8 0}$ & Strongly Disagree & "Very Negative" \\
\hline $\mathbf{1 . 8 1}-\mathbf{2 . 6 0}$ & Disagree & "Negative" \\
\hline $\mathbf{2 . 6 1}-\mathbf{3 . 4 0}$ & Neither Agree nor Disagree & "Average" \\
\hline $\mathbf{3 . 4 1}-\mathbf{4 . 2 0}$ & Agree & "Positive" \\
\hline $\mathbf{4 . 2 1}-\mathbf{5 . 0 0}$ & Strongly Agree & "Very Positive" \\
\hline
\end{tabular}

The data which was gathered through SATTNA was analyzed using SPSS 16.0 (Statistical Package for Social Sciences). To analyze the data in SPSS, frequency and percentage test and Anova test were used. In the analysis of the data, the probability value was accepted as 0,05 to show the statistical significance level of the finding.

\section{Results}

In this section, the results about attitudes of Turkish teachers to the new educational developments/applications are presented.

It can be seen from Table 3 that the teachers' attitudes to the remaining items are average (2.61 - 3.40/ Neither Agree nor Disagree). Furthermore, the total score interval is average $(\bar{x}=3.15)$. 
Table 3. Levels of attitude of Turkish teachers to the new educational developments/applications

\begin{tabular}{|c|c|c|c|}
\hline Scale Items & $\bar{x}$ & Sd & Value \\
\hline 1-I don't act against my truths while teaching Turkish. & 2.68 & 0.88 & Average \\
\hline 2-I don't want to change my way of teaching in Turkish lessons. & 2.92 & 0.65 & Average \\
\hline 3-I value to improve myself in Turkish and basic language skills. & 3.38 & 1.22 & Average \\
\hline $\begin{array}{l}\text { 4-I try to use new and different techniques according to subject, environment and requirements of students } \\
\text { while teaching Turkish. }\end{array}$ & 3.22 & 1.12 & Average \\
\hline 5-The most important component of teaching Turkish is whether students learn. & 3.34 & 1.14 & Average \\
\hline 6-I value and follow new developments to succeed in my profession. & 3.06 & .29 & Average \\
\hline $\begin{array}{l}\text { 7- I reflect interaction between teacher, student and parents is crucial for academic success in Turkish } \\
\text { lessons. }\end{array}$ & 3.32 & 1.05 & Average \\
\hline $\begin{array}{l}\text { 8-I change my way of teaching when I realise that my students don't quite understand what I say (I try } \\
\text { new methods). }\end{array}$ & 3.68 & 1.18 & Positive \\
\hline $\begin{array}{l}\text { 9-I use traditional techniques when I find out that the techniques suggested in Turkish Curriculum don’t } \\
\text { bring success for learning. }\end{array}$ & 3.20 & 1.05 & Average \\
\hline 10-I hold negative attitude to my profession because of new assessment and evaluation instruments. & 3.14 & 1.36 & Average \\
\hline $\begin{array}{l}\text { 11-My undergraduate courses had an influence on my positive attitude to educational innovations and } \\
\text { developments which are helpful for a Turkish teacher. }\end{array}$ & 2.45 & 0.97 & Negative \\
\hline $\begin{array}{l}\text { 12-Attitude of school administration is effective on my new practices and applications which are } \\
\text { appropriate for subject and needs of students. }\end{array}$ & 3.85 & 1.00 & Positive \\
\hline $\begin{array}{l}\text { 13-Socio-cultural environment is important for me to use different methods and techniques to make } \\
\text { subjects quite understandable. }\end{array}$ & 3.98 & 1.12 & Positive \\
\hline $\begin{array}{l}\text { 14-Physical condition of school and classroom (building, classroom size etc.) effects my way of teaching } \\
\text { Turkish. }\end{array}$ & 4.11 & 0.73 & Positive \\
\hline $\begin{array}{l}\text { 15-I attend meetings like seminars, conferences, symposiums and etc. on Turkish, teaching Turkish and } \\
\text { teaching as a profession. }\end{array}$ & 2.66 & 1.27 & Average \\
\hline 16-I don't prefer to lecture about the subjects which are out of guidebook. & 3.22 & 1.34 & Average \\
\hline $\begin{array}{l}\text { 17-I prepare different activities out of student workbook which are appropriate for students-centered and } \\
\text { constructivist learning. }\end{array}$ & 2.64 & 1.32 & Average \\
\hline $\begin{array}{l}\text { 18-I try to adapt the activities in school books to the academic level of students if these activities are not } \\
\text { appropriate for students. }\end{array}$ & 2.50 & 0.08 & Negative \\
\hline 19-I think I got the required training to use different methods, techniques and equipments. & 2.16 & 0.99 & Negative \\
\hline 20-Frequent change in innovations/developments in education influence my motivations to negatively. & 3.54 & 1.26 & Positive \\
\hline Total & \multicolumn{2}{|c|}{3.15} & \\
\hline
\end{tabular}

Table 3 shows that the attitudes of Turkish teachers to the new educational developments/applications are not in the levels of Very Positive (4.21 - 5.00/ Strongly Agree) and Very Negative (1.00 - 1.80/ Strongly Disagree).

However, the teachers' attitudes to the following scale items are negative $(1.81-2.60 /$ Disagree); "My undergraduate courses had an influence on my positive approach to educational innovations and developments which are helpful for a Turkish teacher", "I try to adapt the activities in school books to the academic level of students if these activities are not appropriate for students" and "I think I got the required training to use different methods, techniques and equipments". This finding might be interpreted that pre-service training which the teachers got did not provide sufficient foundations for them in order to adapt themselves to the new educational developments/applications and did not provide sufficient knowledge and skills for them in order to use ICT, different methods and techniques in their classes.

On the other hand, the teachers' attitudes to the following scale items are positive (3.41 - 4.20/Agree); "I change my way of teaching when I realise that my students don't quite understand what I say (I try new methods)", "Attitude of school administration is effective on my new practices and applications which are appropriate for subject and needs of students", "Socio-cultural environment is important for me to use different methods and techniques to make subjects quite understandable", "Physical condition of school and classroom (building, classroom size etc.) effects my way of teaching Turkish" and "Frequent change in innovations/developments in education influence my motivations to negatively".

The attitudes of Turkish teachers to the rest of the items in Table 3 are in Average level (2.61 - 3.40/ Neither Agree nor Disagree). The mean score for all items on the scale is also in Average level ( $\bar{x}=3.15)$. In addition to these findings, the other important findings of the study are the followings: the teachers' attitudes on valuing and following new developments to succeed in their profession is in Average level, the teachers do not lean towards educational innovations and developments because of their pre-service education and the teachers believe that they had lack of trainings in terms of educational innovations and developments. 
Table 4. The analysis of attitudes of Turkish teachers to the new educational developments/applications according to gender

\begin{tabular}{|c|c|c|c|c|c|}
\hline Gender & $\mathbf{N}$ & $\bar{x}$ & Sd & $\mathbf{t}$ & $\begin{array}{c}\text { Significance } \\
\text { level }^{*}\end{array}$ \\
\hline Male & 56 & 3.01 & .31 & 3.540 & 0.001 \\
\hline Female & 69 & 3.22 & .38 & & \\
$* \mathrm{p}<0.05$.
\end{tabular}

Table 4 shows that female teachers $(\bar{x}=3.22)$ hold more positive attitudes to the new educational developments/applications compared to male teachers $(\bar{x}=3.01)$. There is a statistically significant difference between two genders $(\mathrm{p}<0.05)$.

Table 5. The analysis of attitudes of Turkish teachers to the new educational developments/applications according to level of seniority

\begin{tabular}{|c|c|c|c|c|c|}
\hline & $\mathbf{N}$ & $\bar{x}$ & $\mathbf{S d}$ & \multirow{2}{*}{$\mathbf{F}_{(2,122)}$} & $\begin{array}{c}\text { Significance } \\
\text { level }\end{array}$ \\
\hline 1-5 years & 46 & 3.42 & .24 & & \multirow{2}{*}{39.165} \\
\cline { 1 - 3 } 6-10 years & 53 & 2.96 & .34 & \multirow{2}{*}{0.000} \\
\cline { 1 - 3 } 10-15 years & 26 & 2.93 & .26 & & \\
\hline
\end{tabular}

Table 6. Post-Hoc Bonferroni Test

\begin{tabular}{|c|c|c|c|}
\hline $\begin{array}{c}\text { Level of } \\
\text { seniority } \\
(\mathbf{I})\end{array}$ & $\begin{array}{c}\text { Level of } \\
\text { seniority } \\
(\mathbf{J})\end{array}$ & $\begin{array}{c}\text { Mean difference } \\
(\mathbf{I}-\mathbf{J})\end{array}$ & $\begin{array}{c}\text { Significance } \\
\text { level }\end{array}$ \\
\hline $\mathbf{1 - 5}$ years & $\mathbf{6 - 1 0}$ years &, $\mathbf{4 6}\left(^{*}\right)$ &, 000 \\
\hline & $\mathbf{1 0 - 1 5}$ years &, $49\left(^{*}\right)$ &, 000 \\
\hline $6-10$ years & $1-5$ years &,$- 46\left(^{*}\right)$ &, 000 \\
\hline $10-15$ years & $1-5$ years &,$- 49\left(^{*}\right)$ &, 000 \\
\hline
\end{tabular}

It can be seen from the table 5 that the attitudes of the teachers who had 6-10 years teaching experience $(\bar{x}=2.96)$ and the ones who had 10-15 years teaching experience ( $\bar{x}=2.93$ ) to the new educational developments/applications are average while the attitudes of the teachers who had 1-5 teaching experience $(\bar{x}=3.42)$ are positive. There is a statistically significant difference between the teachers' seniority levels and their attitudes to the new educational developments/applications $(\mathrm{p}<0.05)$. The analysis of Post-Hoc Test (Table 6) shows that the teachers who had 1-5 teaching experience hold more positive, statistically proven, attitudes to the new educational developments/applications compared the ones who had 6-10 years and 10-15 years teaching experience $(p<0.05)$. This result may be explained by the fact that the teachers who had 1-5 teaching experience completed their undergraduate education in the recent past so they have fresh and updated academic knowledge about their profession. Another possible explanation for this might be that newly appointed teachers are more capable to adapt themselves to today's technological and social developments.

Table 7 indicates that the attitudes of Turkish teachers in all three types of residential areas to the new educational developments/applications are average. There is a statistically significant difference between the teachers' duty places and their attitudes to the new educational developments/applications $(\mathrm{p}<0.05)$.

Table 7. The analysis of attitudes of Turkish teachers to the new educational developments/applications according to duty place

\begin{tabular}{|c|c|c|c|c|c|}
\hline & $\mathbf{N}$ & $\bar{x}$ & Sd & $\mathbf{F}(\mathbf{2 , 1 2 2})$ & $\begin{array}{c}\text { Significance } \\
\text { level }\end{array}$ \\
\hline City center & 38 & 3,34 &, 380 & & \\
\cline { 1 - 4 } District center & 44 & 2,98 &, 361 & \multirow{2}{*}{12,038} & 0,000 \\
\cline { 1 - 4 } Village & 43 & 3,09 &, 264 & & \\
\hline
\end{tabular}

Table 8. Post-Hoc Bonferroni Test

\begin{tabular}{|c|c|c|c|}
\hline $\begin{array}{c}\text { Duty Place } \\
(\mathbf{I})\end{array}$ & $\begin{array}{c}\text { Duty Place } \\
(\mathbf{J})\end{array}$ & $\begin{array}{c}\text { Mean } \\
\text { Difference } \\
(\mathbf{I}-\mathbf{J})\end{array}$ & $\begin{array}{c}\text { Significance } \\
\text { level }\end{array}$ \\
\hline City center & District center &, $36\left(^{*}\right)$ &, 000 \\
\hline & Village &, $25(*)$ &, 003 \\
\hline District center & City center &,$- 36(*)$ &, 000 \\
\hline Village & City center &,$- 25(*)$ &, 003 \\
\hline
\end{tabular}

The analysis of Post-Hoc Test (Table 8) shows that the Turkish teachers who work in city centers hold more positive, statistically proven, attitudes to the new educational developments/applications compared the ones who work in district centers and villages $(\mathrm{p}<0.05)$. A possible explanation for this might be that the Turkish teachers who work in city centers have more opportunities to access information through various media types and they have more academically successful students.

Table 9 The analysis of attitudes of Turkish teachers to the new educational developments/applications according to education level

\begin{tabular}{|c|c|c|c|c|c|}
\hline & $\mathbf{N}$ & $\bar{x}$ & S.s. & \multirow{2}{*}{$\mathbf{F}_{(\mathbf{2 , 1 2 2})}$} & $\begin{array}{c}\text { Significance } \\
\text { level }\end{array}$ \\
\hline $\begin{array}{c}\text { Bachelor } \\
\text { Degree }\end{array}$ & 97 & 3,09 & 0,338 & & \\
\cline { 1 - 3 } $\begin{array}{c}\text { Master's } \\
\text { Degree }\end{array}$ & 22 & 3,21 & 0,454 & \multirow{2}{*}{4,602} & 0,012 \\
\cline { 1 - 3 } $\begin{array}{c}\text { Doctorate } \\
\text { Degree }\end{array}$ & 6 & 3,55 & 0,366 & & \\
\hline
\end{tabular}

Table 9 indicates that the attitudes of Turkish teachers who had bachelor degree and master's degree to the new educational developments/applications are in Average level ( $\bar{x}=3.09$ and $\bar{x}=3,21$ respectively), while the attitudes of Turkish teachers who had doctorate degree to the new educational developments/applications are in Positive level $(\bar{x}=3.55)$. There is a statistically significant difference between the teachers' education and their attitudes to the new educational developments/applications $(\mathrm{p}<0.05)$.

The analysis of Post-Hoc Test (Table 10) shows that the Turkish teachers who had doctorate degree hold more positive, statistically proven, attitudes to the new educational developments/applications compared the ones who had bachelor degree and master's degree $(p<0,05)$. The table also shows that the Turkish teachers who had master's degree hold more positive attitudes to the new educational developments/applications compared the ones who had bachelor degree but there is a statistically significant 
difference between them. A possible explanation for this might be that the Turkish teachers who had doctorate degree have more knowledge on how to teach, they are more capable of researching and developing themselves academically and they are more able to put their new knowledge on educational developments/applications into practice and change their teaching styles.

Table 10. Post-Hoc Bonferroni Testi

\begin{tabular}{|c|c|c|c|}
\hline $\begin{array}{c}\text { Education } \\
\text { Level } \\
\text { (I) }\end{array}$ & $\begin{array}{c}\text { Education Level } \\
(\mathbf{J})\end{array}$ & $\begin{array}{c}\text { Mean } \\
\text { Difference } \\
(\mathbf{I}-\mathbf{J})\end{array}$ & $\begin{array}{c}\text { Significance } \\
\text { level }\end{array}$ \\
\hline $\begin{array}{c}\text { Bachelor } \\
\text { Degree }\end{array}$ & Master's Degree & $-0,120$ &, 089 \\
\hline $\begin{array}{c}\text { Master's } \\
\text { Degree }\end{array}$ & Doctorate Degree & $-0,339$ &, 178 \\
\hline $\begin{array}{c}\text { Doctorate } \\
\text { Degree }\end{array}$ & Bachelor Degree & $0,460\left(^{*}\right)$ &, 006 \\
\hline
\end{tabular}

\section{Discussion}

Few studies have investigated approaches and attitudes of Turkish teachers to new educational developments / applications related to their profession. In one of them, Helvac1 and Kircioglu [27] investigated preparedness of elementary schools for change and they found that the preparedness level of teachers was average. Kursunoglu conducted a study in Denizli province in 2006 and found that the attitudes of elementary school teachers to change were average [28]. In addition, Ju Park [29] investigated the perceptions of teachers and teacher candidates on interactive whiteboard. She found out that interactive whiteboard increased the interaction between teacher and student, assisted learning and provided more opportunities for group studies. In another study, Selvi [30] found out that teachers thought that opinions about new educational applications were nonsense. It might be seen that the findings of this study are supported by the findings of above mentioned studies. Investigation of awareness and adaptation levels of Turkish teachers to changes in their profession is important for a more quality and successful teaching. Therefore, the study contributed to improvement of quality of education because teachers play the leading role in achievement of goals of every educational innovations. Hence, the findings of the study will be a guide for future studies on language education and teaching Turkish.

\section{Conclusions}

The study which aimed at investigating the attitudes of Turkish teachers to new educational developments/applications based on gender, seniority, duty place and education level variables found the results below:

1) It was found that Turkish teachers had attitudes to new approaches/applications with average level $(\bar{x}=3.15)$. This finding shows that Turkish teachers did not develop complete and enough awareness of new educational developments/applications. The findings also revealed that Turkish teachers did not show positive approaches to new educational developments/applications in sufficient level and this lack of positive attitudes was because of insufficient undergraduate education, school administration, lack of school facility, incomprehensive curriculum and low profile students.

2) There was significant statistical difference on the attitudes of Turkish teachers to new educational developments/applications according to gender, seniority, duty place and education level variables. It was found that female Turkish teachers according to gender variable, teachers having 1-5 years' work experience according to level of seniority variable and the teachers working in city centers according to duty place variable held more positive attitudes to new applications compared to the others. As a result of the findings, it can be said that teachers who had less work experience developed more awareness of new educational developments/applications, updated themselves more frequently, transformed their teaching more easily according to student, subject and environment variables compared to senior teachers. It can also be said that duty places of teachers had an influence on teachers' awareness of new educational developments/applications and on their levels of having information about innovations and using them in their classrooms. A significant statistical difference was found between the attitudes of Turkish teachers who had doctorate degree to new educational developments/applications and the attitudes of Turkish teachers who had bachelor degree and master's degree.

\section{Recommendations}

Considering the results of the study, the required changes should be made in order to raise awareness of Turkish teachers about new educational developments/applications related to their profession, provide opportunities to develop themselves in their profession. With reference to the results of the study, there might be future studies on motivation levels of Turkish teachers and teacher candidates for teaching Turkish, whether they follow changes in process of teaching and adapt themselves to these changes and their levels of knowledge of Turkish Curriculum in terms of different variables.

It seems crucial that teachers should be informed about developments and innovations in Turkish education in their pre-service and in-service education and they should be asked for their feedbacks. In addition, educational changes in regards to developments and innovations in Turkish education should be made after pilot implementations. Turkish education is a teaching period for students in primary and upper-primary levels. In other words, Turkish education in our country focuses on children and young people who are 6-14 years old. It should not be forgotten that students of these ages (concrete and formal operational 
stages) gain the most important developmental skills at the fastest pace. For the children of these ages, the abilities of self-expression and interaction with others are very important. Therefore, educational policy makers should take into account of age characteristics of children when they make educational changes. Furthermore, students and teachers should not face with frequent educational changes. The educational changes should be made according to teachers' opinions and suggestions and education data which gathered through related research studies. The necessary infrastructure should be put in place before implementing those changes.

\section{REFERENCES}

[1] Ministry of Education 2004. İlkogretim Türkçe Dersi (1-5 Siniflar) Ogretim Programı. Ankara, Turkey: ME publications.

[2] Sonmez V (Ed) 2003. Ogretmenlik Meslegine Giris. Ankara: Anı Pub.

[3] Sarac C 2005. Türk dili ve edebiyatı/Türkçe ogretmenlerinin yetistirilmesi. Eurasian Journal of Educational Research, 21, 211-222.

[4] Temizyurek F 2008.Türkce ogretmen adaylarının demografik ozellikleri. Journal of Turkish Education Sciences, 6 (4), 663-692.

[5] Yilmaz M 2007. Sinıf ogretmeni yetistirmede teknoloji egitimi. Journal of Gazi Educational of Faculty, 27(1), 155-167.

[6] Ucar R, Ipek, C 2006. İlkogretim okullarında gorev yapan yonetici ve ogretmenlerin meb hizmet ici egitim uygulamalarına iliskin gorüsleri. Yüzüncü Yıl University Journal of Education Faculty, 3(1), 34-53.

[7] Dusenbury L, Brannigan R, Falco M, Hansen WB 2003. A review of research on fidelity of implementation: Implications for drug abuse prevention in school settings. Health Education Research, 18(2), 237-256.

[8] Kaya E, Cetin PS, Yıldırım A 2012. Transformation of centralized curriculum into classroom practice: An analysis of teachers' experiences. International Journal of Curriculum and Instructional Studies, 2(3), 103-113.

[9] Plant R 1987. Managing change and making it stick. London: Fontana Pub.

[10] Rogers EM 2003. Diffusion of innovations. New York: Free Press of Glencoe.

[11] Toremen F 2002. Egitim orgütlerinde degisimin engel ve nedenleri. Frrat University Journal of Social Sciences, 12(1), 185-202.

[12] Bige, EF, Sarpkaya PY 2015. Teachers' views about the course supervision of primary school principals. Anthropologist, 19(1): 193-204.
[13] Ministry of Education 2005. İlkogretim Türkçe Dersi Ogretim Programı ve Kılavuzu (1-5.Sinıflar). Ankara, Turkey: ME publications.

[14] Ministry of Education 2006. İlkogretim Türkçe Dersi (6, 7 ve 8. Sinıflar) Ogretim Programı. Ankara, Turkey: ME Published.

[15] Celenk S 2002. Ilkokuma-yazma ogretiminde karsılasılan sorunlara iliskin ogretmen gorusleri. Elementary Online, 1 (2), 40-47.

[16] Ministry of Education 2008. Türkçe Ozel Alan Yeterlikleri. Ankara, Turkey: ME publications.

[17] Coskun E, Ozer B, Tiryaki EN 2010. Türkçe ogretmeni adaylarının ozel alan yeterlik algılarının degerlendirilmesi. Dokuz Eylül University Journal of Buca Education Faculty, 27, 117-130.

[18] Kahyaoglu M, Yangın S 2007. Ilkogretim ogretmen adaylarının mesleki ozyeterliklerine iliskin gorüsleri. Kastamonu Journal of Education Faculty, 15 (1), 73-84.

[19] Helvacı MA 2011. Degisime karsı direnis nedenlerini belirleme olcegi.e-Journal of New World Sciences Academy, 6 (3), 2033-2047.

[20] Coskun E 2005. Ilkogretim dorduncu ve besinci sinıf ogretmen ve ogrencilerinin yeni Türkçe dersi ogretim programıla ilgili gorusleri üzerine nitel bir arastırma. Educational Sciences: Theory \& Practice, 5(2), 451-476.

[21] Elvan Z 2007. Türkce (1-5. Sinıflar) ders programının ogretmen goruslerine gore degerlendirilmesi. Unpublished master thesis, Ankara, Turkey: Gazi University Institute of Education Sciences.

[22] Sahin A, Akcay A 2011. Türkçe ogretmeni adaylarının bilgisayar destekli egitime iliskin tutumlarının incelenmesi. Turkish Studies - International Periodical For The Languages, Literature and History of Turkish or Turkic 6(2), 909-918.

[23] Maden S 2012. Teachers' attitudes towards using educational technologies. Energy Education, Science and Technology Part B: Social and Educational Studies, 4(4): 2471-2478.

[24] Katranc1 M, Uygun M 2013. Sınıf ogretmenlerinin Türkçe derslerinde teknoloji kullanımına yonelik gorüsleri. Adiyaman University Journal of Social Sciences, 6(11), 773-797.

[25] Epcacan C 2014. İlkokul ve ortaokul ogretmen ve yoneticilerinin $4+4+4$ egitim sistemine iliskin gorusleri (Siirt ili ornegi). EKEV Journal of Academy, 18(58); 505-522.

[26] Karasar N 2009. Bilimsel Arastırma Yontemi. Ankara: Nobel Pub.

[27] Helvacı MA, Kırcıoglu B 2010. İlkogretim okullarının degisime hazırbulunusluk düzeyleri. Academic Sight International Refereed Online Journal of Social Sciences, 21; $1-30$.

[28] Kursunoglu A 2006. İlkogretim okulu ogretmenlerinin orgütsel degismeye iliskin tutumları (Denizli ili ornegi). Unpublished master thesis, Denizli, Turkey: Pamukkale University Institute of Social Sciences. 
[29] Park J 2014. Pre-Service and in-service teachers' perceptions toward white board system prior to actual experience. Universal Journal of Educational Research, 2(3): 262-270.
[30] Selvi K 2006. Developing a teacher trainees' democratic values scale: validity and reliability analyses. Social Behavior and Personality: An International Journal. 34, (9), 1171-1178. 